\title{
Conservation of fishes in the Elands River, Mpumalanga, South Africa: Past, present and future
}

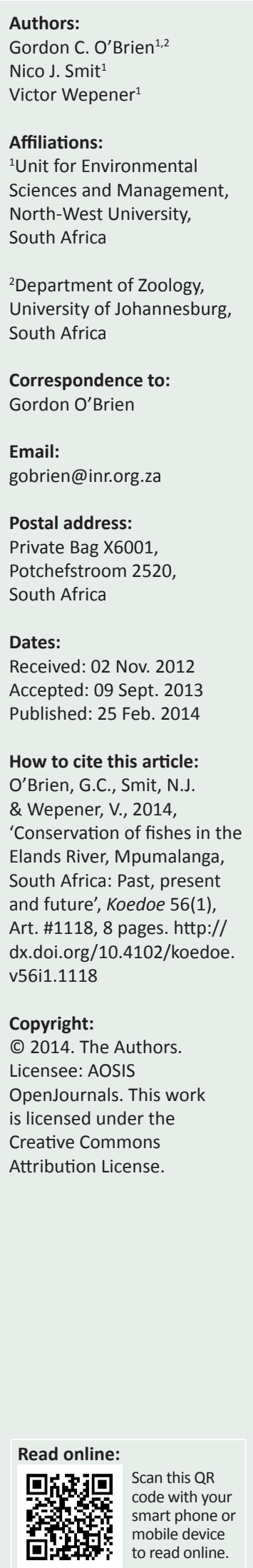

In an isolated reach, between two large natural waterfalls in the Elands River in Mpumalanga, populations of a critically endangered Kneria sp., the endangered Chiloglanis bifurcus and a genetically unique population of Labeobarbus polylepis occur. The aim of this article was to evaluate past efforts to conserve these fishes, describe the current status and propose future conservation and management actions. The population status assessments were based on a series of fish community composition and population structure evaluations from surveys undertaken at 22 sites during seven surveys from 2002 to 2006. Although water-use activities have continued to increase in the area, impacts have been offset by conservation efforts initiated almost 30 years ago. The existing C. bifurcus population appears to be stable, which is reflected in the downgrading of the conservation status of the species from critically endangered to endangered. The abundance of the kneriid population appears to be increasing and spreading to other tributaries in the study area. The abundance of L. polylepis appears to be increasing but has still not reached historical levels.

Conservation implications: Continued conservation efforts are required to protect these fishes. This case study presented a rare example of how the impacts associated with the use of aquatic resources in South Africa can successfully be offset by conservation efforts.

\section{Introduction}

The Elands River is a biologically diverse tributary of the Crocodile River in South Africa which is being used moderately and has been maintained in a suitable integrity state ( $\mathrm{O}^{\prime}$ Brien 2012). A large waterfall $(>10 \mathrm{~m})$ isolates the fish of the Elands River and some tributaries from the Crocodile River Catchment (Gaigher 1969). Within this isolated portion of the Catchment, populations of a critically endangered Kneria sp., the endangered Incomati rock catlet (Chiloglanis bifurcus Jubb \& Le Roux, 1969) and a genetically unique population of the Bushveld smallscale yellowfish (Labeobarbus polylepis Boulenger, 1907) occur (Figure 1) (Engelbrecht \& Bills 2007a; Engelbrecht \& Roux 2002; O'Brien 2009, 2012). Following an accidental spill of paper mill effluent into the Elands River at Ngodwana in 1989 (Kleynhans et al. 1992), the conservation and management of the river received considerable attention (Ferreira, Wepener \& Van Vuren 2008, 2009; Kleynhans et al. 1992). This included the establishment of a sanctuary in the Ngodwana River for C. bifurcus, introduction of a population of Kneria sp. from the upper Crocodile River and the establishment of the Elands River Yellowfish Conservation Area (ERYCA) for the L. polylepis population. Additional conservation efforts include the recommendations that the Elands River be declared a fish sanctuary within the National Freshwater Priority Area (NFEPA) (Driver et al. 2011). The aim of this article is to evaluate the past conservation efforts, describe the current population status and provide management recommendations for the fishes that are threatened and/or unique to the Elands River and its tributaries.

\section{Research method and design \\ Setting}

The study area included the $62 \mathrm{~km}$ reach of the Elands River and its tributaries between the Waterval-Boven and De Villiers Waterfalls and a portion of the Crocodile River upstream and downstream of the Elands River confluence, including the Houtbosloop River (Figure 1). Numerous natural barriers, including the Waterval-Boven Waterfall downstream of Waterval-Boven and De Villiers Waterfall upstream of the Crocodile River confluence on the Elands River, exist in the study area. Other artificial barriers include impoundments on the Ngodwana and Swartkoppies Rivers and a gauging weir on the Elands River (Figure 1). These barriers restrict the movement of fishes in the study area. Numerous activities alter the water quality, quantity and fish habitat in the area, including the Sappi Ngodwana pulp and paper mill, forestry and other agriculture plantations, as well as the urban areas of Machadodorp, Waterval-Boven and Ngodwana (Ferreira et al. 2008, 2009; Hill 2005; O'Brien 2012). Other impacts associated with the occurrence of extralimital and alien fishes also exist in the study area. 


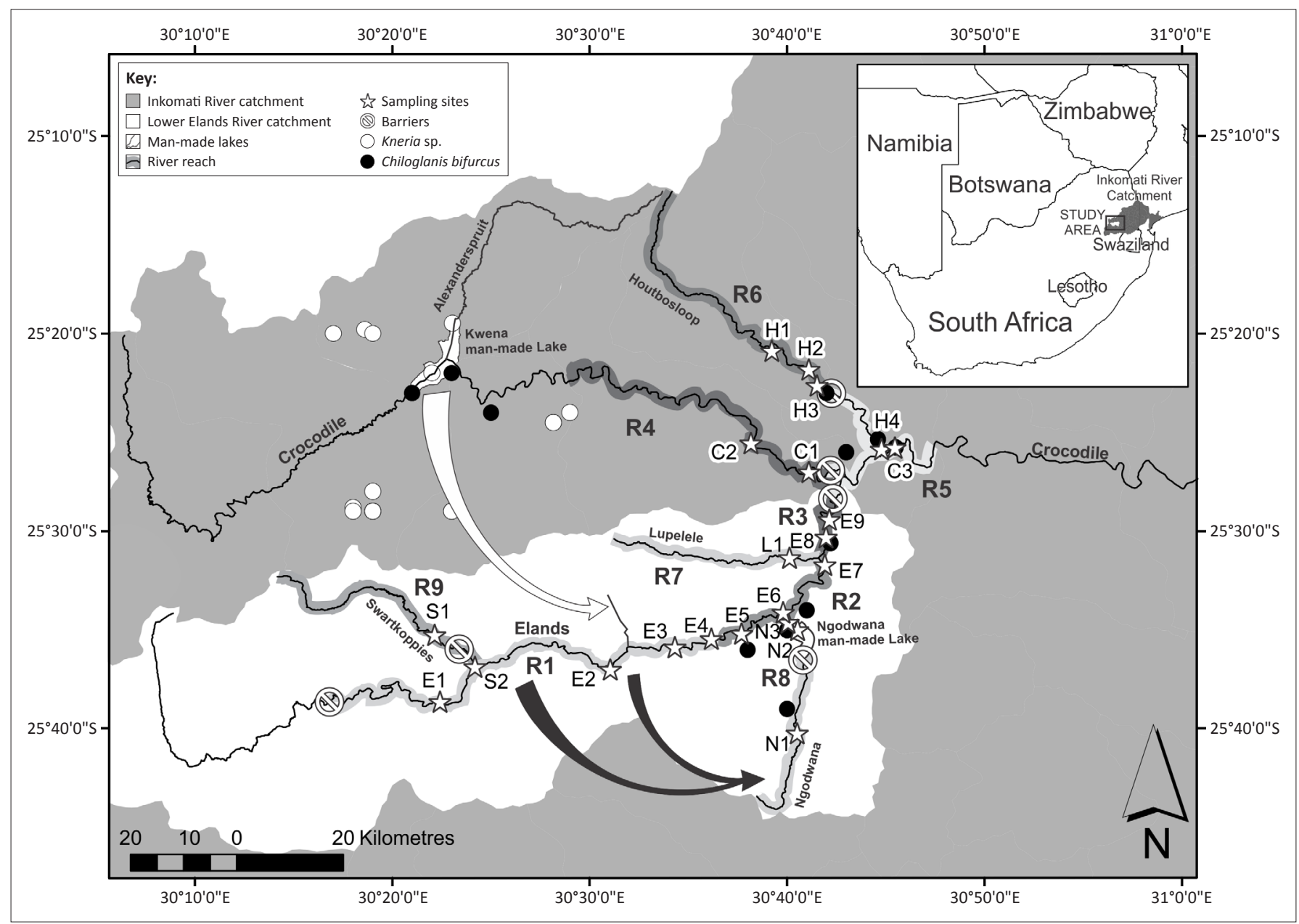

Source: Known locations of Kneria sp. and Chiloglanis bifurcus taken from Scott, L.E.P., Skelton, P.H., Booth, A.J., Verheust, L., Harris, R. \& Dooley, J., 2006, 'Atlas of southern African freshwater fishes', Monograph 2, Smithiana, South African Institute for Aquatic Biodiversity, Grahamstown

The known distributions and relocation paths of Kneria sp. (white arrow) and Chiloglanis bifurcus (black arrow) are depicted. The riverine reaches (R1 to R9) surveyed in the study are highlighted. FIGURE 1: The Elands River and associated rivers within the Inkomati River Catchment, southern Africa, where the populations of fishes that were evaluated in the study occur.

Nine representative river reaches were identified in the study area where surveys were carried out to evaluate the status of fish populations (Figure 1). The criteria considered for reach selection included NFEPA fish sanctuary boundaries, the location of natural and artificial barriers, eco-region boundaries and the spatial extent of important land-use activities. Reach 1 (R1) included the Elands River from the Waterval-Boven Waterfall and the confluence of the Ngodwana River. The Elands River in this reach is a fast-flowing, rejuvenated mountain stream with a well-defined incised channel. Sites E1-E5 were positioned in this reach. Reach 2 (R2) included the Elands River between the confluences of the Ngodwana and Lupulele Rivers below the Sappi pulp and paper-making activities. The Elands River in this reach is dominated by pools and intermittent riffle and rapid complexes. Two sampling sites (E6 and E7) were positioned within R2. Reach 3 (R3) extended from the Lupulele River on the Elands River to the De Villiers Waterfall. The Elands River in R3 is similar to R2 and contains two sampling sites (E8 and E9). Reach 4 (R4) included a uniform reach of the Crocodile River upstream of the confluence with the Elands River where two sites ( $\mathrm{C} 1$ and C2) were located. The habitat type of the Crocodile River in R4 is similar to that which occurs in R2 and R3 in the Elands River.
Poorly managed flow releases from the man-made Kwena Lake are known to impact on this portion of the Crocodile River (O'Brien 2012). Reach 5 (R5) included a portion of the lower Elands, upper Crocodile and lower Houtbosloop Rivers. Two sampling sites (C3 and H4) were located in R5. Reach 6 (R6) included the upper Houtbosloop River above an artificial barrier. This part of the Houtbosloop River can be described as a small, fast-flowing mountain stream that is dominated by riffles and rapids. Three sampling sites $(\mathrm{H} 1-\mathrm{H} 3)$ were positioned within R6. Reach 7 (R7) included the Lupulele River which is a small, slow-flowing clear mountain stream that is dominated by many shallow pools ( $\pm 1 \mathrm{~m}$ deep). One sampling site (L1) was positioned in the lower reaches of the Lupulele River. Reach 8 (R8) included the minimally used upper Ngodwana River above the man-made Ngodwana Lake. The habitat of the upper Ngodwana River in R8 is comparable to the upper Elands (R1) and Houtbosloop Rivers (R6). One sampling site (N1) was located within R8. Reach 9 (R9) included the Swartkoppies River, which is a small mountain stream that has been segmented by artificial barriers to establish pools for a local alien fisheries activity. Two sampling sites were located in R9, one upstream (S1) and one downstream (S2) of the first artificial barrier on the Swartkoppies River. 
TABLE 1: Catch per unit effort of the juveniles, sub-adult and adult Chiloglanis bifurcus and Labeobarbus polylepis collected using electrofishing and gill net sampling techniques during fish community structure assessments of the study from 2002 to 2006.

\begin{tabular}{|c|c|c|c|c|c|c|c|c|c|c|}
\hline \multirow[t]{2}{*}{ Reach } & \multirow[t]{2}{*}{ Site } & \multirow[t]{2}{*}{ Date } & \multicolumn{4}{|c|}{ Chiloglanis bifurcus } & \multicolumn{4}{|c|}{ Labeobarbus polylepis } \\
\hline & & & Juvenile & Sub-adult & Adult & Total & Juvenile & Sub-adult & Adult & Total \\
\hline R 1 & E1 & Mar. 2002 & 0.27 & 0.60 & 0.87 & 1.73 & - & - & - & - \\
\hline R 1 & E2 & Aug. 2002 & - & - & - & - & - & - & $3.00 \dagger$ & $3.00 \dagger$ \\
\hline R 1 & E2 & May 2006 & - & 0.20 & 0.10 & 0.30 & 0.15 & 0.70 & 1.15 & 2.00 \\
\hline R 1 & E3 & Mar. 2002 & 0.05 & 0.18 & 0.09 & 0.32 & - & - & - & - \\
\hline R 1 & E3 & Aug. 2002 & - & - & - & - & - & 0.04 & 0.04 & 0.08 \\
\hline R 1 & E3 & Mar. 2005 & - & - & - & - & - & - & - & - \\
\hline R 1 & E3 & June 2005 & - & 0.04 & - & 0.04 & - & - & - & - \\
\hline R 1 & E4 & Mar. 2005 & - & - & - & - & - & - & - & - \\
\hline R 1 & E5 & June 2005 & - & - & - & - & - & - & - & - \\
\hline $\mathrm{R} 2$ & E5 & Mar. 2002 & - & - & 0.06 & 0.06 & - & - & - & - \\
\hline $\mathrm{R} 2$ & E5 & Aug. 2002 & - & - & - & - & - & - & $0.20 \dagger$ & $0.20 \dagger$ \\
\hline $\mathrm{R} 2$ & E6 & Mar. 2002 & 0.12 & 0.04 & 0.04 & 0.20 & - & 0.04 & 0.12 & 0.16 \\
\hline $\mathrm{R} 2$ & E6 & Aug. 2002 & - & - & - & - & - & - & - & - \\
\hline $\mathrm{R} 2$ & E6 & June 2005 & - & 0.05 & - & 0.05 & - & 0.05 & - & 0.05 \\
\hline $\mathrm{R} 2$ & E7 & Mar. 2002 & 0.08 & 0.08 & 0.04 & 0.20 & - & - & - & - \\
\hline R 2 & E7 & Aug. 2002 & - & - & - & - & - & - & - & - \\
\hline $\mathrm{R} 2$ & E7 & Mar. 2005 & - & - & - & - & - & - & - & - \\
\hline $\mathrm{R} 2$ & E7 & June 2005 & - & - & - & - & - & - & - & - \\
\hline R 3 & E8 & Mar. 2002 & - & 0.05 & - & 0.05 & - & - & - & - \\
\hline R 3 & E8 & Aug. 2002 & - & - & 0.04 & 0.04 & - & - & - & - \\
\hline R 3 & E9 & June 2005 & - & - & - & - & - & - & - & - \\
\hline R 4 & $\mathrm{C} 1$ & Mar. 2002 & - & - & - & - & - & - & - & - \\
\hline R 4 & $\mathrm{C} 1$ & Aug. 2002 & - & - & - & - & - & - & - & - \\
\hline R 4 & $\mathrm{C} 2$ & Mar. 2005 & - & - & - & - & - & - & - & - \\
\hline R 4 & $\mathrm{C} 2$ & June 2005 & - & - & - & - & - & - & - & - \\
\hline R 5 & C3 & Mar. 2002 & 0.13 & - & - & 0.13 & 1.07 & 0.13 & - & 1.20 \\
\hline R 5 & C3 & Aug. 2002 & - & - & 0.05 & 0.05 & - & - & - & - \\
\hline R 5 & $\mathrm{H} 4$ & Mar. 2005 & - & - & - & - & 0.10 & 0.80 & - & 0.90 \\
\hline R 6 & $\mathrm{H} 1$ & Mar. 2005 & - & 0.08 & - & 0.08 & - & - & - & - \\
\hline R 6 & $\mathrm{H} 2$ & Mar. 2005 & - & - & 0.10 & 0.10 & - & - & - & - \\
\hline R 6 & $\mathrm{H} 3$ & Mar. 2005 & - & - & - & - & - & - & - & - \\
\hline R 7 & L1 & Mar. 2005 & - & - & - & - & - & - & - & - \\
\hline R 7 & L1 & June 2005 & - & - & - & - & - & - & - & - \\
\hline R 8 & $\mathrm{~N} 1$ & Apr. 2005 & 0.20 & - & 0.13 & 0.33 & - & 0.07 & - & 0.07 \\
\hline R 8 & $\mathrm{~N} 1$ & June 2005 & - & 0.17 & 0.17 & 0.33 & 0.25 & 0.08 & - & 0.33 \\
\hline R 9 & S1 & Aug. 2006 & - & 0.13 & - & 0.13 & 0.38 & - & 0.13 & 0.50 \\
\hline R 9 & S2 & Aug. 2006 & - & - & - & - & - & - & - & - \\
\hline
\end{tabular}

$\dagger$, using gill net sampling technique.

\section{Procedure}

Seven fish surveys were undertaken from March 2002 to August 2006 during high summer and low winter flow periods at 22 sites (Figure 1) (O'Brien 2009, 2012). In addition, data obtained from a single survey carried out to a shallow $(<1 \mathrm{~m})$ tributary of the Elands River in R1 was included in the study (Figure 1; Palmer pers. comm., 06 August 2012) ${ }^{1}$. Electrofishing was used to collect fish in all shallow $(<1 \mathrm{~m})$ habitats and gill nets were used to collect fishes in deep $(>1 \mathrm{~m})$ habitats. The collected fishes were identified, measured (fork length) and released in close proximity to the collection location. The number of fishes collected per minute of electrofishing and gill net deployments were recorded independently as the catch per unit effort (CPUE). Gill net management consultancy operating out of White River. mesh sizes of $57 \mathrm{~mm}$ and $73 \mathrm{~mm}$ in $25 \mathrm{~m}$ segments were selectively used to target adult L. polylepis individuals in pools. Population structure assessments of the C. bifurcus and L. polylepis were used to evaluate the status of these populations. The proportion of juveniles (young of each year surveyed), immature sub-adults and mature adult individuals collected within each reach of the study area were used to describe the population structures. Population structures were based on length distributions of fishes in relation to attainable lengths (Skelton 2001). Temporal comparisons of CPUE results from Kleynhans et al. (1992) and James (1992) were compared to CPUEs obtained in the study (Table 1 and Figure 2). Trends in the CPUE of C. bifurcus and L. polylepis populations from the study area between 1978-1991 (James 1992; Kleynhans et al. 1992) and 2002-2012 (O'Brien 2009, 2012) were evaluated. Insufficient Kneria sp. samples were collected for inclusion in the population assessment; however, comparisons between 
historical and recent collections allowed for a descriptive assessment of the integrity of the population.

\section{Results}

Sixty-nine C. bifurcus were collected using electrofishing during 18 surveys from seven of the nine reaches sampled during the study (Table 1 and Figure 2). The CPUE rates for $C$. bifurcus ranged between 0.04 and 1.73 individuals per minute when collected. The population structures of this species varied noticeably (Figure 2). High proportions of juvenile, sub-adult and adult $C$. bifurcus individuals were collected at R1 in the Elands River upstream of Ngodwana, downstream of Ngodwana in the Elands River at R2, in the Crocodile River at R5 and in the upper Ngodwana River at R8 (Figure 2). Only adult $C$. bifurcus were collected in the Elands River below the Lupulele River confluence in R3, in

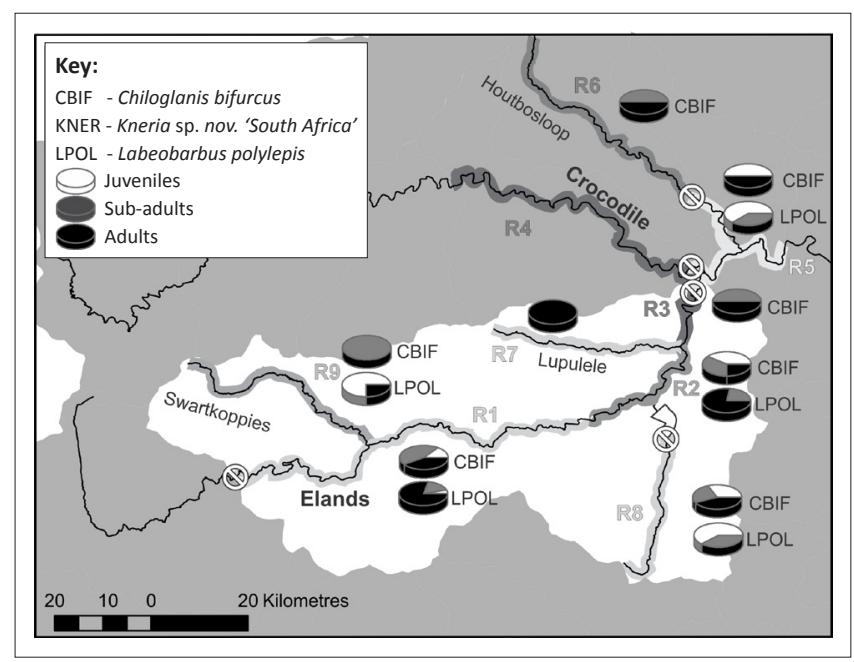

FIGURE 2: Population structure of Chiloglanis bifurcus and Labeobarbus polylepis from each site considered in the study. Charts present percentage proportions of juveniles, sub-adults and adults. the upper Houtbosloop River at R6 and in the Swartkoppies River at R9. A noticeable decrease in the CPUE of $C$. bifurcus in the Elands and Crocodile Rivers from R1 and R2 to R3 and R5 were observed (Table 1).

From October 1989, the CPUE of C. bifurcus populations in four of the six reaches sampled reduced noticeably (Figure 3). The CPUE of the population in the upper Elands and Houtbosloop Rivers remained relatively stable for at least another year until March 1990. During June and September 1990, the lowest abundance of C. bifurcus (CPUE < 0.20) was observed. From October 1990 to September 1991, the CPUEs of C. bifurcus populations in many reaches fluctuated considerably and then returned to low levels in October 1991. From March 2002 to August 2006, apart from a CPUE of 1.73 in R1 during March 2002, the CPUE of C. bifurcus populations did not exceed 0.33 individuals per minute (Table 1 and Figure 3).

One hundred and twenty-three L. polylepis individuals were collected on 13 occasions in the study area during the electrofishing and gill net efforts from eight sites representing five reaches of the study area (Table 1). The CPUE rates for L. polylepis ranged between 0.00 and 0.04 when collected, to 1.20 fish per minute using electrofishing techniques and 0.00-3.00 fish per minute using gill netting techniques (Table 1). Shoaling behaviour of L. polylepis was observed where numerous (5-45 individuals) were collected together. The local L. polylepis population preferred deep pools during winter where they were actively targeted using gill nets (O'Brien 2009). These deep pool areas were uncommon in the upper reaches of the Elands River, the Swartkoppies, Lupulele and Ngodwana Rivers but common in the middle and lower Elands River (R2 and R3). In R1 alone, all size categories of L. polylepis were collected. Adult L. polylepis dominated the upper portion of the Elands River in the study

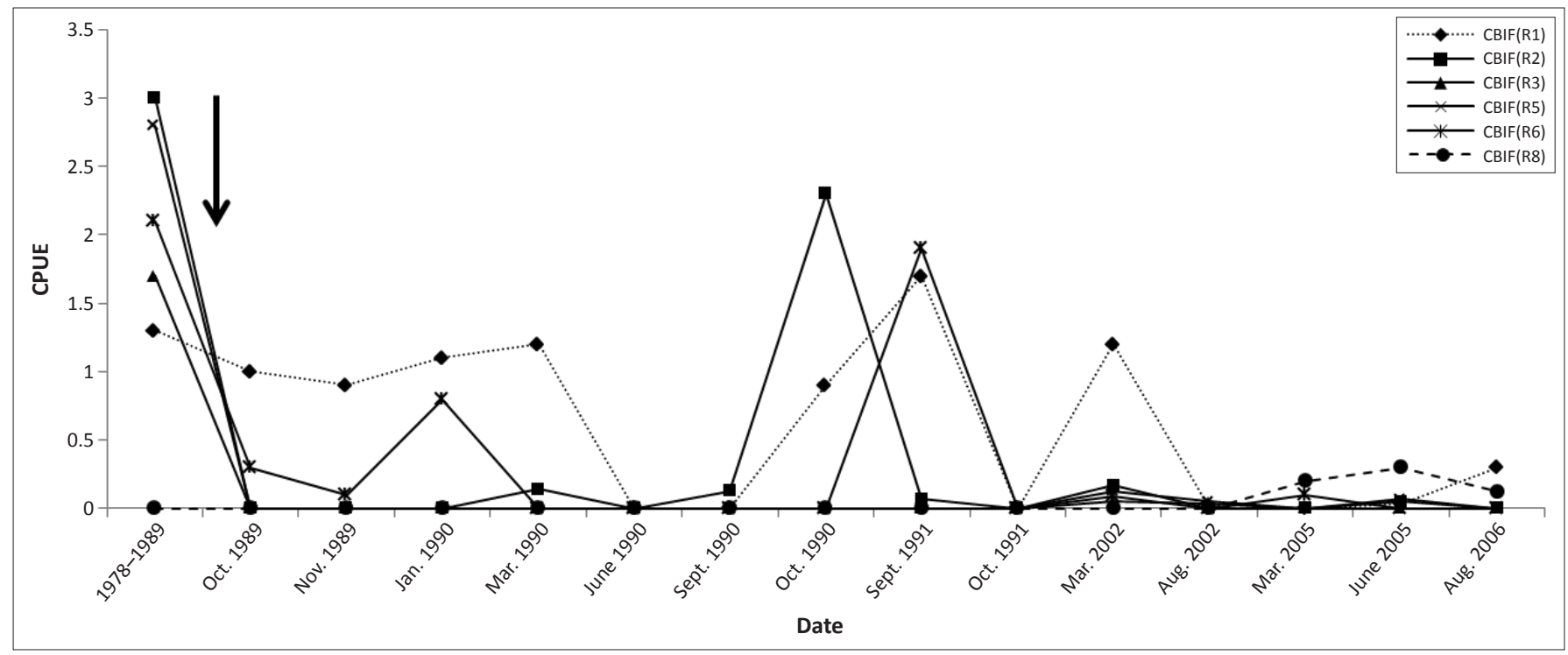

Source: The 1978-1989 taken data from Kleynhans et al. 1992. The October 1989-2006 data taken from James 1992; Kleynhans et al. 1992; O'Brien 2009. For more information on these sources, see the full reference list of the article: O'Brien, G.C., Smit, N.J. \& Wepener, V., 2014, 'Conservation of fishes in the Elands River, Mpumalanga, South Africa: Past, present and future', Koedoe 56(1), Art. \#1118, 8 pages. http://dx.doi.org/10.4102/koedoe.v56i1.1118

CBIF, Chiloglanis bifurcus; CPUE, catch per unit effort.

FIGURE 3: Temporal trends in the catch per unit effort (number of fish per minute) of Chiloglanis bifurcus collected in the Elands River between 1978 and 1989 (mean of available data) and between October 1989 and 2006. Arrow depicts the occurrence of the 1989 black liquor spill into the Elands River. 
area and the lower Swartkoppies River sites, (R1, R2 and R9). Juvenile L. polylepis were common in the upper reaches of the Ngodwana (R8) and Swartkoppies (R9) Rivers and in the Crocodile River in the vicinity of the confluence of the Houtbosloop River at R5.

Although L. polylepis were collected between 1978 and October 1991, no CPUE data are available for this period. From 2002, large abundances L. polylepis were initially collected from R1 and R5 in the Elands River, and from R8 in the upper Ngodwana River (Figure 4). The observed CPUEs varied considerably and were influenced by the shoaling behaviour of L. polylepis. These findings were substantiated in 2004 following the discovery of large shoals of adult L. polylepis in R1 of the Elands River in February 2004 (ERYCA 2004). In addition, during the spring of 2004, large numbers of L. polylepis were observed migrating upstream in the Elands River, approximately $5 \mathrm{~km}$ below the WatervalBoven Waterfall (ERYCA 2004).

In 2007, approximately 50 Kneria sp. were collected in the unnamed tributary of the Elands River (R1) using electrofishing techniques. Although no CPUE data are available, these findings show that the Kneria sp. population relocated into R1 remains in relatively large abundances (Palmer pers. comm., 06 August 2012).

\section{Ethical considerations}

The fisheries biology research presented in this paper was carried out under the authorisation of Mpumalanga Parks and Tourism permits issues on the 09 March 2005 (MPB. 5131/2), 31 January 2006 (MPB. 5161), 24 January 2007 (MPB. 5184) and 02 June 2008 (MPB. 5222).

\section{Discussion}

It is well known that the fish communities of the Elands River vary spatially and temporally throughout the study area (Gaigher 1969; James 1992; Kleynhans et al. 1992; O'Brien 2012). Apart from the effects of natural barriers, artificial physical and chemical barriers have been identified as major

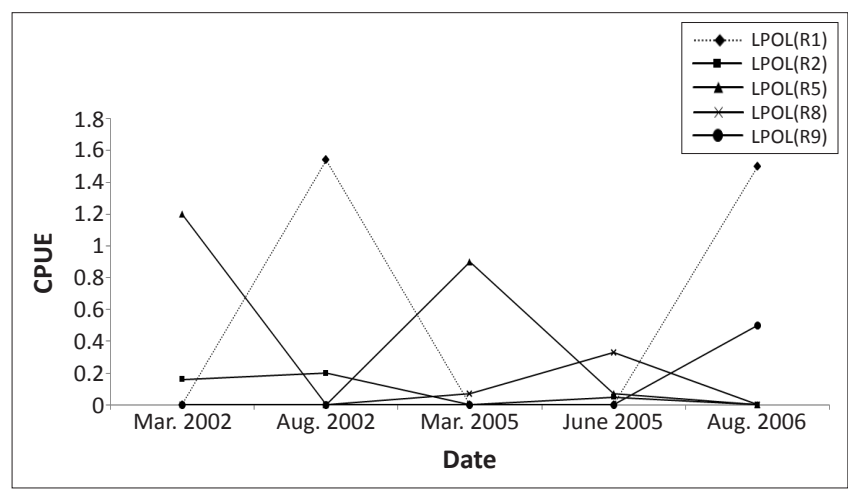

Source: The 2002-2006 data taken from O'Brien, G.C., 2009, 'Aspects of the ecology and population management of the Bushveld smallscale yellowfish (Labeobarbus polylepis)', Water Research Commission report KV225/09, pp. 21-52, Water Research Commission, Pretoria CPUE, catch per unit effort; LPOL, Labeobarbus polylepis.

FIGURE 4: Temporal trends in the catch per unit effort (number of fish per minute) of Labeobarbus polylepis collected in the Elands River between 2002 and 2006. threats that affect fish community structures in the study area (O'Brien 2012). Other impacts attributed to shifts in fish community structures included habitat availability and water quality and quantity alterations of natural and anthropogenic origin (O'Brien 2012). Abundant, well-structured populations of C. bifurcus and L. polylepis that contained high proportions of juvenile, sub-adult and adult individuals occurred in the Elands River, Swartkoppies and Ngodwana Rivers prior to the pollution events in the mid-to-late 1980s (Gaigher 1969; Kleynhans et al. 1992). These pollution events included a series of small to moderate $(<5000 \mathrm{~L})$ chemical spills into the Elands River in February 1985, July 1986, June 1989 and culminated in the large effluent spill in September 1989 (Kleynhans et al. 1992). These events caused the C. bifurcus and L. polylepis population structures to change considerably, particularly downstream of the source of the spills, in the vicinity of Ngodwana and the lower Elands River into the upper Crocodile River (Kleynhans et al. 1992). Although by 1992 some recovery had occurred, the abundance of individuals has not recovered to pre-1980 levels (James 1992; Kleynhans et al. 1992).

Until the recent discovery of a population of C. bifurcus in Swaziland (Monadjem et al. 2003), the known distribution of C. bifurcus was restricted to the upper Crocodile River and the Elands River and its major tributaries (Skelton 2001). Following an evaluation of the effects of the chemical spill into the Elands River on 23 September 1989, conservation efforts for these populations were initiated (Kleynhans et al. 1992). James (1992) proposed that the species be allocated critically endangered status because of the noticeable reduction in distribution and abundance of populations in the Elands and upper Crocodile Rivers. In 1996, C. bifurcus was formally assigned critically endangered status by the International Union for Conservation of Nature (IUCN) (Engelbrecht \& Bills 2007a). The vulnerability criteria included the restricted distribution of the remaining populations in the Inkomati River Catchment (Figure 1) and intolerance to water quality and flow alterations (Engelbrecht \& Bills 2007a; James 1992). In addition, James (1992) recommended that a sanctuary be established in the upper Ngodwana River for the local Elands River population and in the Houtbosloop River for the Crocodile River population. In 1992, a small population of C. bifurcus individuals $(n= \pm 100)$ were relocated into the Ngodwana River for this purpose.

Apart from the Lupulele River (R7) and upper Crocodile River (R4) reaches, the C. bifurcus populations still extend throughout the study area and now include the upper Ngodwana River (R8). The most abundant populations occur in the upper Elands (R1), Ngodwana (R8) and Crocodile Rivers (R5). From the findings, we can surmise that although the local C. bifurcus population has been affected by the spill in 1989, other events or activities may have affected local populations. Some of the reductions in the CPUE of C. bifurcus populations were observed from 1990 and occurred in areas that were not affected by the spill. From August 2002 to 2006, 17 years after the spill, the CPUE scores of all C. bifurcus populations had still not recovered to levels 
observed prior to 1989 (Figure 3). In 2007, however, after the discovery of a population of C. bifurcus in Swaziland (Monadjem et al. 2003), the conservation status of $C$. bifurcus was amended to endangered (Engelbrecht \& Bills 2007a; Scott et al. 2006; Skelton 1993, 2001).

The abundance of the local L. polylepis population also decreased substantially in 1989 following the chemical spill into the Elands River (Kleynhans et al. 1992). Despite the occurrence of known unique morphological features of the local population from 1969 (Gaigher 1969), relocations of L. polylepis individuals from the Komati River to the Elands River occurred between 1993 and 1996 in an attempt to increase the abundances of the local population (Engelbrecht pers. comm., 03 June 2006) ${ }^{2}$. Although actual numbers of individuals released were not recorded, it is estimated that between 35 and 50 were released into the Elands River, upstream of Ngodwana at Hemlock, and into the manmade Ngodwana Lake. These conservation efforts formed part of a conservation plan for the L. polylepis population in the Elands River developed by Roux (2008). In addition, a captive breeding programme was initiated in an attempt to breed and restock L. polylepis into the Elands River (ERYCA 2004). In 2000, a Oncorhynchus mykiss (Walbaum 1792) breeding facility (trout farm) at Arlie Estates (located in the upper reaches of the study area, R1) was stocked with L. polylepis individuals from the Komati River for the breeding programme. The culturing efforts were not successful and no L. polylepis from Arlie Estates were released into the Elands River.

In 2004, the ERYCA strategy was developed to conserve the fishes of the Elands River using L. polylepis as a flagship species (ERYCA 2004). Then, in 2004, Mulder et al. discovered that consistent genetic variation occurred between isolated L. polylepis populations. Based on these findings and recommendations made by the ERYCA strategy, a morphological and genetic diversity and ecological evaluation of the local L. polylepis population was undertaken $\left(\mathrm{O}^{\prime}\right.$ Brien 2009). Findings of the study confirmed that the Elands River L. polylepis population is genetically and morphologically unique, with unique biological aspects (O'Brien 2009).

In 1983, approximately 200 individuals of an undescribed, critically endangered Kneria sp. population from the Alexander Spruit were relocated into a tributary of the Elands River (Figure 1) (Engelbrecht \& Bills 2007b; Kleynhans pers. comm., 11 November 2012) $)^{3}$. The distribution range of these knerians is restricted to the upper Crocodile River above the confluence with the Elands River in Mpumalanga (Figure 1). The population of the Kneria sp. in the Alexander Spruit was threatened by habitat destruction associated with the construction of the man-made Kwena Lake (Figure 1). Other threats include population fragmentation, predation by

2.Dr Johan Engelbracht is a former fisheries scientist of the Mpumalanga Parks and Tourism, based in Lydenburg, Mpumalanga.

3.Dr C.J. Kleynhans is the Chief Specialist Scientist at Resource Quality Services, Department of Water Affairs, Roodplaat, and a former ecologist of the Transvaal Chie Directorate of Nature and Environmental Conservation, Karenpark. alien fishes (e.g. O. mykiss) and water quality and habitat altering water resource use activities (Engelbrecht \& Bills 2007b). Some fragmented populations have become extinct as a result of these threats (Engelbrecht \& Bills 2007a). The remaining natural area of habitation by the Kneria sp. is less than $10 \mathrm{~km}^{2}$. The tributary of the Elands River where the knerians were relocated to was considered to be suitable for the establishment of a sanctuary for this critically endangered species (Engelbrecht \& Bills 2007b). Although no Kneria sp. individuals were collected in the Elands River in close proximity to the relocation point between 2002 and 2006 , the collection of numerous individuals $(n= \pm 50)$ in a small tributary of the Elands River in 2007 other than the release site, indicates that the relocated population still exists 29 years after the relocation and may now occur in at least two tributaries of the Elands River.

\section{Conservation requirements}

The conservation efforts in the study area have had varying degrees of success. In particular, the continued survival of the Kneria sp. population is encouraging. The endangered C. bifurcus population from the study area still exists in low but stable abundances when compared with historical CPUEs (Figure 3). The conservation efforts to establish a population of C. bifurcus in the Ngodwana River have been successful and results showed that this population is stable and increasing. The only population of C. bifurcus that appears to be decreasing is the population in the Houtbosloop River, which has continuously reduced from 1992. The local L. polylepis population in the Elands River appears to be stable and increasing in abundance. The continued management and conservation of the Elands River and its tributaries is of great importance for the continued conservation efforts of these fishes. In accordance, the Elands River Catchment has been selected as a fish sanctuary within the NFEPA programme (Nel et al. 2011).

The large number and diversity of water resource use activities in the study are known to pose a threat to the viability of the populations of local fishes (O'Brien 2012). These stressors include water quality and quantity impacts and threats from alien and invasive fishes and habitat alterations (O'Brien 2012). Water quality alteration threats include point source pollution events such as the chronic accidental spill and the continuous diffuse release of effluent from the pulp and paper mill, various agriculture activities in the area and partially treated effluent from the Machadodorp, Waterval-Boven and Ngodwana wastewater treatment works (Ferreira et al. 2009; O'Brien 2012). Water quantity impacts include the alteration of volume, timing and duration of flows in the Elands River by the pulp and paper-making activities at Ngodwana, which includes the management of the man-made Ngodwana Lake (Ferreira et al. 2009; O'Brien 2012). The man-made Ngodwana Lake is a $10 \mathrm{~m}^{3} \times 10^{6} \mathrm{~m}^{3}$ water storage facility that was constructed in the early 1980s on the lower Ngodwana River, a tributary of the Elands River. Shortly after construction, a recreational sport angling activity was established by local community 
members who established extra-limital populations of the mozambique tilapia (Oreochromis mossambicus), redbreast tilapia (Tilapia rendalli), sharptooth catfish (Clarias gariepinus), sidespot barb (Barbus neefi), the silver robber (Micralestes acutidens) and bushveld smallscale yellowfish (L. polylepis) and alien species including common carp (Cyprinus carpio), largemouth bass (Micropterus salmoides) and rainbow trout (O. mykiss) in the lake (ERYCA 2004; Schroeder pers. comm., 16 February 2005) ${ }^{4}$. Many of these alien fishes have established populations in the Elands River and some of its tributaries (O'Brien 2012). Oncorhynchus mykiss individuals are still being stocked into the Elands River upstream of the Swartkoppies River confluence and into the Swartkoppies River to maintain the fly-fishing activities in these areas (ERYCA 2004).

\section{Recommendations}

Although the abundance of the C. bifurcus population in the Ngodwana River is increasing, the abundance of the individuals in the Houtbosloop River has decreased. In the Elands River, although the C. bifurcus population is lower than historical levels, the abundances do not appear to be decreasing. Continued monitoring and protection measures are required. Efforts similar to those established in the Ngodwana and Elands Rivers should be developed for the Houtbosloop River and other populations in the Inkomati Catchment. This should include an assessment of the genetic diversity of isolated C. bifurcus populations.

The possibility that the critically endangered Kneria sp. has established itself in the other tributaries of the Elands River is encouraging, but needs validation. The status of the original remaining populations in the upper Crocodile River is largely unknown and should also be considered. The critically endangered conservation status of this species is likely to remain for the foreseeable future.

Although the abundance of the unique L. polylepis population in the Elands River appears to be increasing, numerous threats to the sustainability of the population still exist. The continued conservation of the local L. polylepis population should be encouraged through awareness and the implementation of conservation plans. Financial resources availability continues to be a limitation for these conservation endeavours. The development of a sustainable catch and release angling industry for the local L. polylepis population should be considered. Similar industries have been established in other parts of South Africa, such as the Vaal River where the local yellowfish-dependent angling industry is valued at over R133 million per annum (Brand et al. 2009). Wepener and Chapman (2012) argue that, for the protection of biodiversity, there should be a shift away from conserving ecosystem health towards ecosystem services. Therefore the potential to establish an economic value associated with the conservation of fishes could contribute greatly to the sustainability of conservation efforts.

4.Mr E.W. Schroeder is the former Chairman of the Ngodwana Boating and Angling Club, Ngodwana.

\section{Conclusion}

In the almost 30 years following the initiation of conservation efforts for fishes in the Elands River, the threats to local populations have continued to increase. The impacts of the threats have, however, been offset by the conservation efforts established in the area. Although utilised, the Elands River and its associated tributaries are considered to be in a healthy state (O'Brien 2012). Although recoveries from the 1989 events appear to be ongoing 24 years later, the populations of fishes appear to be growing. This case study presents a rare example of how the impacts associated with the use of aquatic resources in South Africa can successfully be offset by conservation efforts. In addition, it is only because of the availability of long-term monitoring data that the status of the populations can be evaluated. These actions have all been established and/or carried out within the context of existing management and conservation endeavours with the willingness of the local stakeholders to maintain biodiversity and keep ecosystem service use sustainable.

\section{Acknowledgements}

The financial contributions made to this study by Sappi (Pty) Ltd, the Department of Trade and Industry (THRIP programme) and the Water Research Commission are acknowledged. We further would like to thank Mr N. James, Dr C.J. Kleynhans, Dr J.S. Engelbrecht, Mr F. Roux and Dr W. Vlok for specialist advice and the BSc Honours and MSc students from the Centre of Aquatic Research at the University of Johannesburg who carried out their studies on the system. Finally, we would like to thank participants of the ERYCA workshop and members of the Elands River conservancy who facilitated this work, in particular the late Mr George Harvermaul, Garth Johnson and Dave Hempson from the ERYCA.

\section{Competing interests}

The authors declare that they have no financial or personal relationships that may have inappropriately influenced them in writing this article.

\section{Authors' contributions}

G.C.O. (North-West University) was responsible for the study conceptualisation, data collection and iteration, analyses, report writing and editing, whilst N.J.S. (NorthWest University) contributed to the study conceptualisation, data iteration, report writing and editing and V.W. (NorthWest University) contributed to the study conceptualisation, report writing and editing.

\section{References}

Brand, M., Maina, J., Mander, M. \& O'Brien, G., 2009, 'Characterisation of the social and economic value of the use and associated conservation of the yellowfishes in the Vaal River', Water Research Commission report KV226/09, Water Research Commission, Pretoria.

Driver, A., Nel, J.L., Snaddon, K., Murray, K., Roux, D.J., Hill, L. et al., 2011, 'Technical report for the Freshwater Ecosystem Priority Areas Project', Water Research Commission report 1801/2/11, pp. 16-22, Water Research Commission, Pretoria. 
Elands River Yellowfish Conservation Area, 2004, 'Elands River Yellowfish Conservation Area: Conservation plan', Outcomes of the stakeholders workshop for the establishment of the Elands River Yellowfish Conservation Area strategy, hosted by the Elands River Conservancy, Ntsinini, 28 August.

Engelbrecht, J. \& Bills, R., 2007a, 'Chiloglanis bifurcus', in IUCN Red List of Threatened Species, version 2012.1, viewed 03 September 2012, from http://www.iucnredlist. org

Engelbrecht, J. \& Bills, R., 2007b, 'Kneria sp. nov. South Africa', in IUCN Red List of Threatened Species, version 2012.1, viewed 03 September 2012, from http://www. iucnredlist.org

Engelbrecht, J.S. \& Roux, F., 2002, 'Fish', in A.J. Emery, M. Lötter \& S.D. Williamson (eds.), 'Determining the conservation value of land in Mpumalanga', pp. 137-146, unpublished report prepared for the Department of Water Affairs and Forestry and Department for International Development, by the Mpululanga Parks Board, Lydenburg.

Ferreira, M., Wepener, V. \& Van Vuren, J.H.J., 2008, 'Die invloed van papierpulpmeuleaktiwiteite op die visgemeenskapstruktuur van die Elandsrivier, Mpumalanga', Suid-Afrikaanse Tydskrif vir Natuurwetenskap en Tegnologie 27, 83-94.

Ferreira, M., Wepener, V. \& Van Vuren, J.H.J., 2009, 'Spatial and temporal variation in the macroinvertebrate community structure of the lower Elands River, Mpumalanga, South Africa', African Journal of Aquatic Science 34, 231-238. http://dx.doi. org/10.2989/AJAS.2009.34.3.4.980

Gaigher, I.G., 1969, 'Aspekte met betrekking tot die ekologie, geographie en taksonomie van varswatervisse in die Limpopo en Incomatiriviersisteem', PhD thesis, Department of Zoology, Rand Afrikaans University.

Hill, L., 2005, 'Elands catchment comprehensive reserve determination study, Mpumalanga Province, ecological classification and ecological water requirements (quantity) workshop report', Contract report for Sappi-Ngodwana ENV-P-C 2004-019, pp. 1-98, submitted to the Department Water Affairs and Forestry, by the Division of Wate Environment and Forestry Technology, CSIR, Pretoria.

James, N.P.E., 1992, 'The conservation status of the Incomati rock catlet Chiloglanis bifurcus, in the Elands River, Eastern Transvaal, and research into artificial propagation', South African Institute for Aquatic Biodiversity investigational report 40, SAIAB, Grahamstown.
Kleynhans, C.J., Schulz, G.W., Engelbrecht, J.S. \& Roussaeu, F.J., 1992, 'The impact of a paper mill effluent spill on the fish populations of the Elands and Crocodile Rivers (Inkomati System, Transvaal)', Water SA 18, 73-80.

Monadjem, A., Boycott, R., Parker, V. \& Culverwell, J., 2003, 'Threatened vertebrates of Swaziland', in Swaziland Red Data book: Fishes, amphibians, reptiles, birds and mammals, pp. 66-72, Ministry of Tourism, Environment and Communication, Mbabane.

Mulder, P.F.S., Engelbrecht, D., Engelbrecht, J.S. \& Roux, F., 2004, 'Biochemical genetic variation between four populations of Labeobarbus polylepis from three river systems in South Africa', African Journal of Aquatic Science 29, 97-102. http:// dx.doi.org/10.2989/16085910409503797

Nel, J.L., Murray, K.M., Maherry, A., Petersen, C.P., Roux, D.J., Driver, A.L. et al., 2011 'Technical report for the National Freshwater Ecosystem Priority Areas Project', Water Research Commission technical report 1801/2/11, pp. 16-17, Water Research Commission, Pretoria.

O'Brien, G.C., 2009, 'Aspects of the ecology and population management of the Bushveld smallscale yellowfish (Labeobarbus polylepis)', Water Research Commission report KV225/09, pp. 21-52, Water Research Commission, Pretoria.

O’Brien, G.C., 2012, 'Regional scale risk assessment methodology using the relative risk model as a management tool for aquatic ecosystems in South Africa', PhD thesis, Department of Zoology, University of Johannesburg.

Roux, F., 2008, 'Status of the Bushveld smallscale yellowfish', in N.D. Impson, I.R. Bills \& L. Wolhuter (eds.), Technical report on the state of yellowfishes in South Africa in 2007 KV212/08, pp. 65-72, Water Research Commission, Pretoria.

Scott, L.E.P., Skelton, P.H., Booth, A.J., Verheust, L., Harris, R. \& Dooley, J., 2006, 'Atlas of southern African freshwater fishes', Monograph 2, Smithiana, South African Institute for Aquatic Biodiversity, Grahamstown.

Skelton, P.H., 1993, A complete guide to the freshwater fishes of southern Africa, 1st edn., Southern Publishers (Pty.) Ltd., Halfway House. PMCid:PMC1491714

Skelton, P.H., 2001, A complete guide to the freshwater fishes of southern Africa, 2nd edn., Southern Publishers (Pty.) Ltd., Halfway House.

Wepener, V. \& Chapman, P.M., 2012 'South African ecotoxicology - Present status and future prognosis', African Journal of Aquatic Science 37(3), 229-234. http:// dx.doi.org/10.2989/16085914.2012.717051 